\title{
R. L. Krueger, Antoine de La Sale's "Petit Jehan de Saintré" and the Comte de Tressan. Libertinage, gallantry and French identity in an eighteenth-century adaption
}

\section{Martina Crosio}

\section{(2) OpenEdition}

\section{Journals}

Édition électronique

URL : http://journals.openedition.org/studifrancesi/10583

DOI : $10.4000 /$ studifrancesi. 10583

ISSN : 2421-5856

Éditeur

Rosenberg \& Sellier

Édition imprimée

Date de publication : 1 décembre 2017

Pagination : 553

ISSN : 0039-2944

Référence électronique

Martina Crosio, «R. L. Krueger, Antoine de La Sale's "Petit Jehan de Saintré" and the Comte de Tressan. Libertinage, gallantry and French identity in an eighteenth-century adaption », Studi Francesi [En ligne], 183 (LXI | III) | 2017, mis en ligne le 01 février 2018, consulté le 21 janvier 2021. URL : http://

journals.openedition.org/studifrancesi/10583; DOI : https://doi.org/10.4000/studifrancesi.10583

Ce document a été généré automatiquement le 21 janvier 2021.

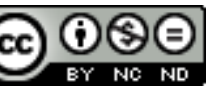

Studi Francesi è distribuita con Licenza Creative Commons Attribuzione - Non commerciale - Non opere derivate 4.0 Internazionale. 
R. L. Krueger, Antoine de La Sale's

"Petit Jehan de Saintré" and the Comte de Tressan. Libertinage, gallantry and French identity in an eighteenthcentury adaption

\author{
Martina Crosio
}

\title{
RÉFÉRENCE
}

Roberta L. Krueger, Antoine de La Sale's "Petit Jehan de Saintré" and the Comte de Tressan. Libertinage, gallantry and French identity in an eighteenth-century adaption, in «Cahiers de Recherches Médiévales et Humanistes» 30, 2015, pp. 329-351.

1 Le Petit Jehan de Saintré (1780) du Comte de Tressan, généralement peu étudié et jugé sévèrement par la critique, mérite d'être redécouvert: le succès extraordinaire dont il a joui jusqu'au xix ${ }^{\mathrm{e}}$ siècle a en fait permis la circulation et la survie dans la mémoire collective de l'histoire rédigée en 1456 par Antoine de La Sale. En resituant la réécriture dans le contexte socio-culturel de la France de la fin du xviiie siècle, R.L. Krueger analyse les modifications, les omissions et les ajouts que le remanieur - tel un prosateur du Moyen Âge tardif - a apportées au texte-source pour l'adapter aux goûts et à la sensibilité du nouveau public. Le résultat de ces changements est un texte condensé et profondément différent de son modèle: Tressan, qui se concentre sur l'histoire d'amour et sur les aspects psychologiques de l'intrigue, transforme le récit courtois à visée didactique d'Antoine de La Sale en un roman sentimental captivant. 